\title{
Pharmacological treatment of central neuropathic pain: consensus of the Brazilian Academy of Neurology
}

\author{
Tratamento farmacológico da dor neuropática central: consenso da Academia \\ Brasileira de Neurologia
}

Rogério Adas Ayres de OLIVEIRA',2, Abrahão Fontes BAPTISTA ${ }^{3}$, Katia Nunes SÁ4, Luciana Mendonça BARBOSA 1,2, Osvaldo José Moreira do NASCIMENTO2,5, Clarice Listik' Xavier MOISSET ${ }^{6}$,

Manoel Jacobsen TEIXEIRA ${ }^{1,7}$, Clinicians participants of the panel of experts

recommended by the Brazilian Academy of Neurology ${ }^{8}$, Daniel Ciampi de ANDRADE 1,2,7

\begin{abstract}
Background: Central neuropathic pain (CNP) is often refractory to available therapeutic strategies and there are few evidence-based treatment options. Many patients with neuropathic pain are not diagnosed or treated properly. Thus, consensus-based recommendations, adapted to the available drugs in the country, are necessary to guide clinical decisions. Objective: To develop recommendations for the treatment of CNP in Brazil. Methods: Systematic review, meta-analysis, and specialists opinions considering efficacy, adverse events profile, cost, and drug availability in public health. Results: Forty-four studies on CNP treatment were found, 20 were included in the qualitative analysis, and 15 in the quantitative analysis. Medications were classified as first-, second-, and third-line treatment based on systematic review, meta-analysis, and expert opinion. As first-line treatment, gabapentin, duloxetine, and tricyclic antidepressants were included. As second-line, venlafaxine, pregabalin for CND secondary to spinal cord injury, lamotrigine for CNP after stroke, and, in association with first-line drugs, weak opioids, in particular tramadol. For refractory patients, strong opioids (methadone and oxycodone), cannabidiol/delta9-tetrahydrocannabinol, were classified as third-line of treatment, in combination with first or second-line drugs and, for central nervous system (CNS) in multiple sclerosis, dronabinol. Conclusions: Studies that address the treatment of CNS are scarce and heterogeneous, and a significant part of the recommendations is based on experts opinions. The CNP approach must be individualized, taking into account the availability of medication, the profile of adverse effects, including addiction risk, and patients' comorbidities.
\end{abstract}

Keywords: Pain; Pain management; Neuropathic pain; Drug therapy; Consensus.

\section{RESUMO}

Introdução: A dor neuropática central (DNC) é frequentemente refratária às estratégias terapêuticas disponíveis e há poucas opções de tratamento baseado em evidência. Muitos pacientes com dor neuropática não são diagnosticados ou tratados adequadamente. Desse modo, recomendações baseadas em consenso, adaptadas à disponibilidade de medicamentos no país, são necessárias para guiar decisões

\footnotetext{
${ }^{1}$ Universidade de São Paulo, Faculdade de Medicina, Centro de Dor, Departamento de Neurologia, São Paulo SP, Brazil.

${ }^{2}$ Academia Brasileira de Neurologia, Departamento Científico de Dor, São Paulo SP, Brazil.

${ }^{3}$ Universidade Federal do ABC, Center for Mathematics, Computation and Cognition, São Bernardo do Campo SP, Brazil.

«Escola Bahiana de Medicina e Saúde Pública, Graduate and Research Department, Salvador BA, Brazil.

5Universidade Federal Fluminense, Faculdade de Medicina, Graduate and Research Program in Neurology/Neurosciences, Niterói RJ, Brazil.

${ }^{6}$ Université Clemont Auvergne, Chu de Clermont-Ferrand, INSERM, NEURO-DOL, F-63000 Clermont-Ferrand, France.

7 Universidade de São Paulo, Departamento de Neurologia, Centro de Dor, LIM 62, São Paulo SP, Brazil.

${ }^{8}$ Academia Brasileira de Neurologia, Departamento Científico de Dor, São Paulo SP, Brasil. (Abouch Krymchantowski, Alberto Rolim Muro Martinez, Alcione Mendes de Sousa, Alyne Mendonça Marques Ton, Silva Tenorio Luna Sarmento, André Palma da Cunha Matta, Antonio Rodrigues Coimbra Neto, Bruno Bertoli Esmanhotto, Camila Castelo Branco Pupe, Clarice Listik, Eduardo Boiteux Uchôa Cavalcanti, Eliana Meire Melhado, Eustáquio Claret dos Santos, Fabricio Diniz de Lima, Fabíola Dach, Helena Rezende Silva Mendonça, Hilton Mariano, Igor Silvestre Bruscky, Ingrid Faber, Jefferson Borges de Oliveira, Jessyca Luana Alves Koslyk, Jorge Dornellys da Silva Lapa, Jose Fabio Santos Leopoldino, José Geraldo Speciali, Marcelo Rezende Young Blood, Marcelo Silva Cabral, Marcos Moreira, Matheus Gurgel Saraiva, Mauro Eduardo Jurno, Michel Elyas Jung Haziot, Miriam Jaqueline Teixeira, Nestor C Truite Jr, Norma Regina Pereira Fleming, Otto J H Fustes, Patricia Peixoto, Pedro Schestatsky, Renata Gomes Londero, Renato Silva Martins, Sidney Gomes, Welber Sousa Oliveira, Wladimir Bocca V. de Rezende Pinto, Yara Dadalti Fragoso).

Rogério Adas Ayres de OLIVEIRA (iD https://orcid.org/0000-0002-0254-8497;Abrahão Fontes BAPTISTA (iD https://orcid.org/0000-0001-7870-3820;

Katia Nunes SÁ (iD https://orcid.org/0000-0002-0255-4379; Luciana Mendonça BARBOSA (iD) https://orcid.org/0000-0002-5239-5935;

Osvaldo José Moreira do NASCIMENTO iD https://orcid.org/0000-0003-3516-485X; Clarice LISTIK (iD https://orcid.org/0000-0002-7660-3970;

Xavier MOISSET (iD https://orcid.org/0000-0002-8799-0750;Manoel Jacobsen TEIXEIRA (iD https://orcid.org/0000-0002-7974-6045;

Clinicians participants of the panel of experts recommended by the Brazilian Academy of Neurology; Daniel Ciampi de ANDRADE (iD https://orcid.org/0000-0003-3411-632X Correspondence: Daniel Ciampi de Andrade; E-mail: ciampi@usp.br

Conflict of Interest and financial support: KNS (third author) received financial aid from Zodiac Produtos Farmacêuticos to develop this guideline. DCA and AFB received productivity in research scholarships from the National Council for Scientific and Technological Development. All authors declare no other conflicts of interest to develop the study.

Author's contribution: R. A. A. de Oliveira - Methodology, Writing - original draft; A. F. Baptista - Formal Analysis, Writing - original draft; K. N. Sá - Data curation, Formal Analysis; L. M. Barbosa - Funding acquisition, Project administration; O. J. M. do Nascimento - Methodology, Data curation, Visualization; C. ListikWriting - review \& editing; X. Moisset - Formal Analysis, Data curation; M. J. Teixeira - Conceptualization, Methodology; D. C. de Andrade - Conceptualization, Funding acquisition, Project administration, Writing - review \& editing; Central Neuropathic Pain Study Group - Methodology, Formal Analysis.

Received on July 4, 2020; Received in its final form on September 6, 2020; Accepted on September 17, 2020.
} 
clínicas. Objetivo: Desenvolver recomendações para o tratamento da DNC no Brasil. Métodos: Revisão sistemática, metanálise e discussão dos resultados entre especialistas e pesquisadores da área, considerando eficácia, perfil de eventos adversos, custo e disponibilidade do fármaco na saúde pública. Resultados: Foram encontrados 44 estudos sobre tratamento da DNC, dos quais 20 foram incluídos na análise qualitativa e 15, na quantitativa. Classificaram-se as medicações em primeira, segunda e terceira linhas de tratamento, baseando-se em revisão sistemática, meta-análise e opinião de especialistas. Como primeira linha, foram incluídos gabapentina, duloxetina e antidepressivos tricíclicos. Como segunda, venlafaxina, pregabalina para DNC secundária à lesão medular, lamotrigina para DNC pós-acidente vascular cerebral e, em associação aos fármacos de primeira linha, opioides fracos, em particular tramadol. Para os pacientes refratários, opioides fortes (metadona e oxicodona) e canabidiol/delta-9-tetrahidrocanabinol foram classificados como terceira linha de tratamento, em associação com drogas de primeira ou segunda linha, e, para DNC na esclerose múltipla, dronabinol. Conclusões: Os estudos que abordam o tratamento da DNC são escassos e heterogêneos, e parte significativa das recomendações é baseada em opiniões de especialistas. A abordagem da DNC deve ser individualizada, levando em conta a disponibilidade de medicação, o perfil de efeitos adversos, incluindo risco de dependência e as comorbidades do paciente.

Palavras-chave: Dor; manejo da dor; dor neuropática central; tratamento farmacológico; consenso.

\section{INTRODUCTION}

Chronic pain is defined as pain in one or more anatomical regions that persists or recurs for longer than three months and is associated with significant emotional distress or functional disability ${ }^{1}$. It affects from 19 to $41 \%$ of the general population living in developing countries ${ }^{2}$. Neuropathic pain (NP) is defined as pain arising from lesion or disease to the somatosensory pathways ${ }^{3}$. Chronic pain with neuropathic characteristics affects from 6.9 to $10 \%$ of the worldwide general population ${ }^{4}$, and it is present in 10 to $14.5 \%$ of the Brazilian population ${ }^{5}$.

Central neuropathic pain (CNP) refers to neuropathic pain that results from a lesion or disease of the central somatosensory nervous system. The prevalence of CNP has been less frequently assessed in the general population, but it is estimated to affect a significant proportion of patients with different neurological diseases, such as $18 \%$ of stroke survivors who have somatosensory deficits ${ }^{6}$, and $59 \%$ of those affected by spinal cord injury ${ }^{7}$, and at least $30 \%$ of multiple sclerosis patients 8 . Despite its high prevalence, the heavy functional burden, and impact on the patients' quality of life, CNP is often misdiagnosed or neglected, even by specialists.

There is a paucity of guidelines and consensus to support the CNP management, which may lead not only to uncontrolled pain, but also to undesired side-effects due to inadequate prescription. Pharmacological treatment for CNP is generally accepted as the first treatment. However, despite the significant advances in pharmacotherapy in recent decades, complete relief from NP is rare $^{10}$. The results of monotherapy approaches remain unsatisfactory ${ }^{11}$, leading to the frequent association of drugs that are often not supported by evidence or recommendations. Furthermore, there are limitations of cost and access to several medications for NP treatment, including those classified as first-line therapy, and, especially, for the newest and most expensive drugs, in the Brazilian public health care system (Sistema Único de Saúde-SUS).

The response of non-pharmacological interventions to CNP such as neuromodulation approaches, despite newer recommendations, suffer from similar limitations, such as restricted evidence of efficacy in this type of pain, as well as cost-related issues ${ }^{12}$.

With this in mind, and pressed by the need to propose pharmacological interventions that make sense in view of the current evidence, providing lower risks of side-effects and which are available for the general population, a consensus recommendation was conducted based on a systematic review and meta-analysis of the literature and also based on the opinion of experts when the evidence was conflicting or controversial. This consensus was headed by the Scientific Department on Pain of the Brazilian Academy of Neurology as part of its quadrennial mission.

\section{METHODS}

This study followed the Appraisal of Guidelines Research \& Evaluation (AGREE) reporting checklist for the development of consensus papers ${ }^{13}$. Details on the methods can be found in supplementary material.

\section{RESULTS AND DISCUSSION}

\section{Systematic review of the literature and formulation of the first recommendation}

The initial search in the literature retrieved 219 studies, 33 of which were selected for full reading. Manual search identified 11 more, resulting in 44 studies (Figure 1). After full reading of those studies, only 20 were included in the qualitative analysis and 15 in the quantitative synthesis. The studies by Finnerup et al. (2002) ${ }^{14}$, Jungehulsing et al. (2013) Drewes et al. $(1994)^{16}$, and Vestergaard et al. $(2001)^{17}$ were excluded from quantitative synthesis because they did not present means and standard deviations as central and dispersion measures, making it imprecise to include them in the meta-analysis ${ }^{18}$. The study by Leijon et al. $(1989)^{19}$ was also excluded from the quantitative synthesis as, in addition to having presented mean and standard deviations as central 


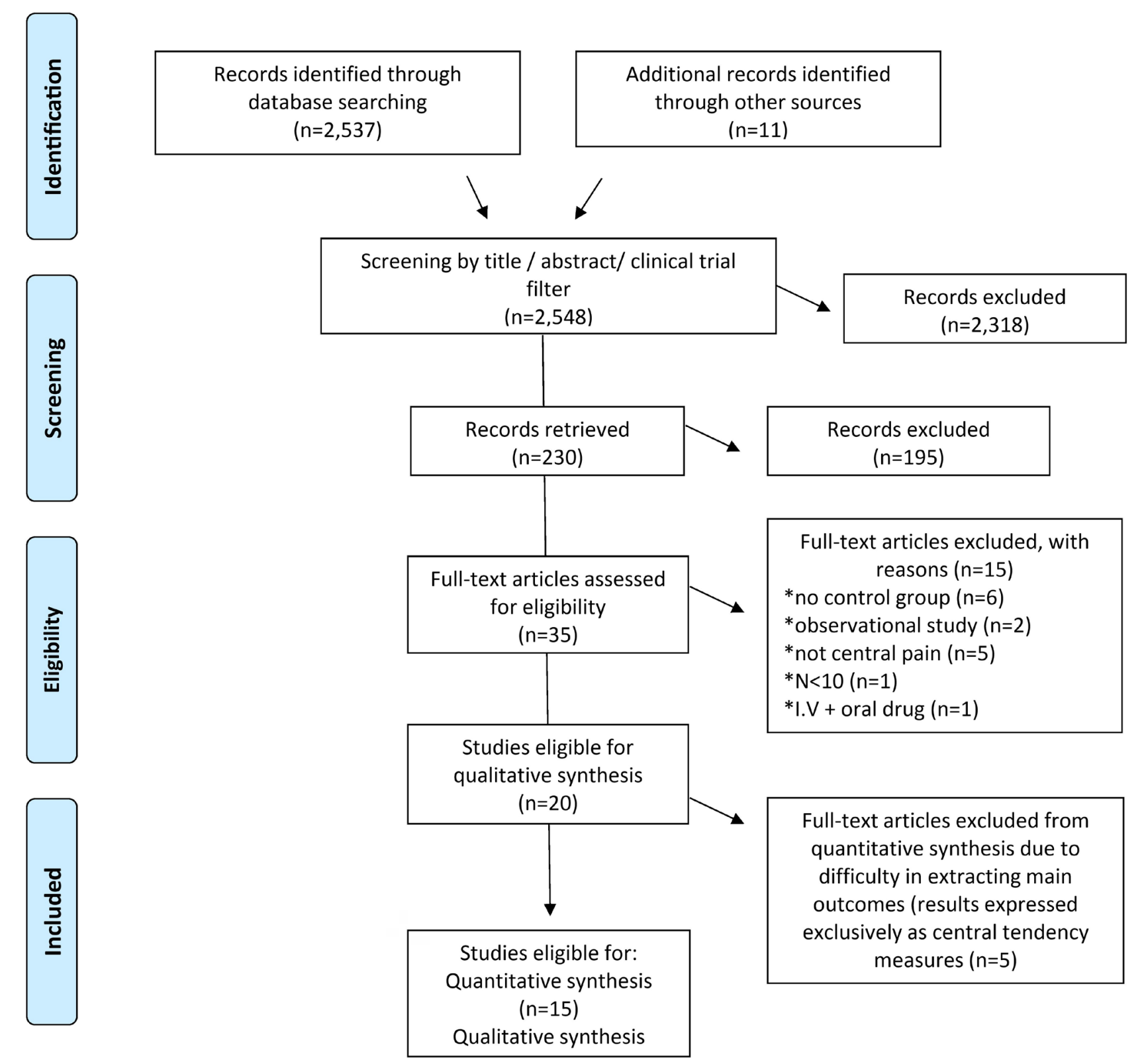

Figure 1. Flowchart of the literature search in Medline (via Pubmed).

tendency and dispersion measures, the statistical analysis was performed with non-parametric tests, making these measures inappropriate. The 20 studies included pharmacological agents employed in the treatment of central pain in multiple sclerosis ${ }^{20,21,22,23,24,25,26,27,28}$, spinal cord injury ${ }^{16,22,27,29,30}$, stroke $^{15,20-22,31}$, and brachial plexus injury with avulsion ${ }^{32}$. They used as pharmacological agents pregabalin ${ }^{20,21,22,31}$, gabapen$\operatorname{tin}^{29}$, duloxetine ${ }^{26,27,30}$, amitriptyline ${ }^{19}$, combinations of cannabidiol/delta-9-tetrahydrocannabinol $\quad(\mathrm{CBD} / \mathrm{THC})^{14,24,32,33}$, lamotrigine ${ }^{14,15,24}$, levetiracetam ${ }^{15}$, carbamazepine ${ }^{19}$, dronabinol $^{28}$, and valproate ${ }^{16}$.

Fifteen studies were excluded for not having a control group ${ }^{34,35,36,37,38,39}$, for being observational instead of randomized controlled trials $(\mathrm{RCT})^{38,40}$, for including individuals with pain other than $\mathrm{CNP}^{41,42,43,44,45}$, for having less than 10 participants in the treatment $\mathrm{arm}^{46}$, and for using oral and intravenous drugs in association ${ }^{47}$.

The quantitative synthesis showed that pharmacological treatment with the above-described drugs significantly decreased pain intensity (Supplementary Figure S1). However, there was a great heterogeneity among the studies $\left(\mathrm{I}^{2}=93 \%\right)$, making this statement inconsistent. Then, a separate meta-analysis was run by grouping different drugs in the treatment of CNP. A second general quantitative synthesis was performed including studies in which all or all-butone GRADE items were considered as low-risk of bias $(\mathrm{n}=8)$. This second analysis showed an overall efficacy (large effect size - 0.85[0.49-1.22]) for the use of pharmacological agents to 
treat CNP (Supplementary Figure S2), this time with higher homogeneity $\left(\mathrm{I}^{2}=24 \%\right)$. This second analysis included six positive studies using pregabalin ${ }^{21,22}$, and duloxetine ${ }^{30}$ to treat spinal cord injury (SCI)-CNP, and formulations of $\mathrm{CBD} / \mathrm{THC}^{33,37}$ and duloxetine ${ }^{26}$ to treat multiple sclerosis-related CNP, as well as two studies using lamotrigine ${ }^{23}$ and levetiracetam ${ }^{24}$, and dronabinol ${ }^{28}$ to treat MS-CNP, and one study using pregabalin to treat central poststroke pain (CPSP) ${ }^{31}$.

The classification of studies according to the European Federation of Neurological Societies (EFNS) criteria was the next step in the definition of the final recommendations of this guideline (Table 1). This table also contains the

Table 1. Main results from selected studies.

\begin{tabular}{|c|c|c|c|c|c|c|c|}
\hline Studies & Drug/condition & $\begin{array}{l}\text { Line of } \\
\text { treatment } \\
\text { according to the } \\
\text { consensus }\end{array}$ & $\begin{array}{l}\text { Results } \\
(+/-)\end{array}$ & $\begin{array}{c}\text { EFNS } \\
\text { Classification }\end{array}$ & $\begin{array}{c}\text { Level of } \\
\text { Recommendation }\end{array}$ & $\begin{array}{l}\text { Adverse } \\
\text { effects }\end{array}$ & $\begin{array}{l}\text { Availability in } \\
\text { SUS / Mean cost } \\
\text { per month }\end{array}$ \\
\hline $\begin{array}{l}\text { Levendoglu et al } \\
2004\end{array}$ & Gabapentin/SCl & first-line & + & ॥ & $\begin{array}{c}\text { C } \\
\text { (Possibly } \\
\text { effective) }\end{array}$ & ++ & $\begin{array}{c}\text { Available } \\
\text { (Formulary } \\
\text { for high cost } \\
\text { medicines) } / \$ \$ \$\end{array}$ \\
\hline $\begin{array}{l}\text { Vranken et al., } \\
2011\end{array}$ & $\begin{array}{c}\text { Duloxetine/ } \\
\text { CPSP, SCl }\end{array}$ & \multirow{3}{*}{ first-line } & - & ॥ & \multirow{3}{*}{$\begin{array}{c}\text { C } \\
\text { (Possibly } \\
\text { effective) }\end{array}$} & \multirow{3}{*}{++} & \multirow{3}{*}{ Not available / \$\$ } \\
\hline $\begin{array}{l}\text { Vollmer et al., } \\
2013\end{array}$ & Duloxetine/MS & & + & I & & & \\
\hline $\begin{array}{l}\text { Brown et al., } \\
2015\end{array}$ & $\begin{array}{c}\text { Duloxetine/ } \\
\text { MS }\end{array}$ & & + & II & & & \\
\hline $\begin{array}{l}\text { Leijon et al., } \\
1989\end{array}$ & $\begin{array}{l}\text { Amitriptyline/ } \\
\text { CPSP }\end{array}$ & first-line & + & ॥ & $\begin{array}{c}\text { C } \\
\text { (Possibly } \\
\text { effective) }\end{array}$ & +++ & Available /\$ \\
\hline $\begin{array}{l}\text { Siddal et al., } \\
2006\end{array}$ & $\begin{array}{l}\text { Pregabalin/ } \\
\text { SCl }\end{array}$ & \multirow{4}{*}{ second-line } & + & ॥ & $\begin{array}{c}\text { C } \\
\text { (Possibly } \\
\text { effective) }\end{array}$ & \multirow{4}{*}{++} & \multirow{4}{*}{$\begin{array}{l}\text { Not available / } \\
\$ \$ \$\end{array}$} \\
\hline $\begin{array}{l}\text { Cardenas et al., } \\
2013\end{array}$ & Pregabalin/SCI & & + & । & & & \\
\hline $\begin{array}{l}\text { Vranken et al., } \\
2008\end{array}$ & $\begin{array}{l}\text { Pregabalin/ } \\
\text { CPSP, SCI }\end{array}$ & & + & ॥ & & & \\
\hline Kim et al., 2011 & $\begin{array}{l}\text { Pregabalin/ } \\
\text { CPSP }\end{array}$ & & - & I & & & \\
\hline $\begin{array}{l}\text { Vestergaard } \\
\text { et al., } 2001\end{array}$ & $\begin{array}{l}\text { Lamotrigine/ } \\
\text { CPSP }\end{array}$ & \multirow{3}{*}{ second-line } & + & $\|$ & \multirow{3}{*}{$\begin{array}{c}\text { B } \\
\text { (Possibly } \\
\text { ineffective) }\end{array}$} & \multirow{3}{*}{++} & \multirow{3}{*}{ Not available / \$\$ } \\
\hline $\begin{array}{l}\text { Breuer et al., } \\
2007\end{array}$ & Lamotrigine/MS & & - & II & & & \\
\hline $\begin{array}{l}\text { Finnerup et al., } \\
2002\end{array}$ & Lamotrigine/SCl & & - & II & & & \\
\hline $\begin{array}{l}\text { Svendsen et al., } \\
2004\end{array}$ & $\begin{array}{c}\text { THC } \\
\text { (Dronabinol)/MS }\end{array}$ & \multirow{5}{*}{ Third-line } & + & ॥ & \multirow{5}{*}{$\begin{array}{c}\text { B } \\
\text { (Probably } \\
\text { effective)* }\end{array}$} & \multirow{5}{*}{+++} & \multirow{5}{*}{$\begin{array}{l}\text { Not available / } \\
\qquad \$ \$ \$\end{array}$} \\
\hline $\begin{array}{l}\text { Berman et al., } \\
2004\end{array}$ & $\mathrm{CBD} / \mathrm{THC} / \mathrm{BPI}$ & & + & II & & & \\
\hline Rog et al., 2005 & CBD/THC/MS & & + & । & & & \\
\hline $\begin{array}{l}\text { Langford et al., } \\
2013\end{array}$ & $\mathrm{CBD} / \mathrm{THC} / \mathrm{MS}$ & & - & II & & & \\
\hline $\begin{array}{l}\text { Schimrigk et al., } \\
2017\end{array}$ & $\begin{array}{c}\text { THC } \\
\text { (Dronabinol)/MS }\end{array}$ & & - & ॥ & & & \\
\hline $\begin{array}{l}\text { Falah et al., } \\
2011\end{array}$ & $\begin{array}{c}\text { Levetiracetam/ } \\
\text { MS }\end{array}$ & Non-favorable & - & II & \multirow{2}{*}{$\begin{array}{c}\text { B } \\
\text { (Probably } \\
\text { ineffective) }\end{array}$} & \multirow{2}{*}{+++} & \multirow{2}{*}{$\begin{array}{l}\text { Not available / } \\
\qquad \$ \$\end{array}$} \\
\hline $\begin{array}{l}\text { Jungehulsing } \\
\text { et al., } 2012\end{array}$ & $\begin{array}{l}\text { Levetiracetam/ } \\
\text { CPSP }\end{array}$ & Non-favorable & - & II & & & \\
\hline $\begin{array}{l}\text { Leijon et al., } \\
1989\end{array}$ & $\begin{array}{c}\text { Carbamazepine/ } \\
\text { CPSP }\end{array}$ & $\begin{array}{l}\text { Favorable } \\
\text { in selected } \\
\text { patients }\end{array}$ & - & ॥ & $\begin{array}{c}\text { C } \\
\text { (Possibly } \\
\text { ineffective) }\end{array}$ & +++ & Available / \$ \\
\hline
\end{tabular}




\begin{tabular}{|c|c|c|c|c|c|c|c|}
\hline Studies & Drug/condition & $\begin{array}{l}\text { Line of } \\
\text { treatment } \\
\text { according to the } \\
\text { consensus }\end{array}$ & $\begin{array}{l}\text { Results } \\
(+/-)\end{array}$ & $\begin{array}{c}\text { EFNS } \\
\text { Classification }\end{array}$ & $\begin{array}{c}\text { Level of } \\
\text { Recommendation }\end{array}$ & $\begin{array}{l}\text { Adverse } \\
\text { effects }\end{array}$ & $\begin{array}{l}\text { Availability in } \\
\text { SUS / Mean cost } \\
\text { per month }\end{array}$ \\
\hline $\begin{array}{l}\text { Chiou-Tan et al., } \\
1996\end{array}$ & Mexiletine/SCI & Non-favorable & - & ॥ & $\begin{array}{c}\text { C } \\
\text { (Possibly } \\
\text { ineffective) }\end{array}$ & & \\
\hline $\begin{array}{l}\text { Drewes et al., } \\
1994\end{array}$ & Valproate/SCl & Non-favorable & - & ॥ & $\begin{array}{c}\text { C } \\
\text { (Possibly } \\
\text { ineffective) }\end{array}$ & & \\
\hline
\end{tabular}

EFNS: European Federation of Neurological Societies; SCI: Spinal Cord Injury; CPSP: Central post-stroke Pain; MS: Multiple Sclerosis; BPI: Brachial Plexus Injury (with avulsion); CBD: Canabidiol; THC: Delta-9-Tetrahydrocannabinol . *One should consider this recommendation with caution, as formulations and doses are quite different between studies. The initial level A recommendation was downgraded to level $\mathrm{B}$ because of this heterogeneity. Drugs without research evidence:Venlafaxin and Opioids. \$: low cost, $\$$ : medium cost, $\$ \$$ : high cost, $\$ \$ \$$ : very high cost; + low adverse effects; ++ low/medium adverse effects; +++ high adverse effects.

final recommendations based on the ratings of 12 specialists from the Brazilian Academy of Neurology, who voluntarily responded to the query to vote in the second round of the study. An agreement above $90 \%$ was obtained for the recommendations. These ratings took into account the results of the quantitative synthesis, the EFNS level of recommendation, the availability of the drugs in the Brazilian public health system, their cost, side-effect profile, and historical national clinical experience with each drug. Drugs were eventually classified as of first-, second- and third-line according to all these factors.

\section{Consensus recommendation}

\section{First-line therapy}

\section{Duloxetine}

The use of duloxetine to treat CNP associated with multiple sclerosis was based on two studies. In a low-quality, class I, positive study, Vollmer et al. used doses of $60 \mathrm{mg}$ (30 mg for one week, followed by $60 \mathrm{mg}$ for five weeks) followed by a 12 week-open-label extension phase (30-120 mg/day) ${ }^{27}$. Outcomes included daily changes in pain intensity, pain impact on daily activities, quality of life, anxiety/depression, fatigue, and patients' global impression of improvement. Results showed only a small decrease, although statistically significant, in pain intensity at week six, accompanied by significant discontinuation of the intervention due to adverse events.

Brown et al. used duloxetine to treat CNP in multiple sclerosis patients, in a high-quality, positive, class II study ${ }^{26}$. Participants were treated with $30 \mathrm{mg} /$ day for one week, followed by $60 \mathrm{mg} /$ day for five weeks, and $30 \mathrm{mg} /$ day for one week, completing seven weeks of intervention. The average daily pain was reduced by $39 \%$ in the active group compared to $10 \%$ in the placebo group. Adverse events included nausea, dizziness, fatigue, constipation, and urinary retention. Vranken et al. also used duloxetine (60 and $120 \mathrm{mg} /$ day) in patients with CNP caused by spinal cord or stroke in a highquality, class II, positive study ${ }^{30}$. They have found that duloxetine did not affect the mean pain score and pressure pain thresholds after eight weeks, but alleviated dynamic and cold allodynia. Also, they observed improvement for the bodily pain domain of the Short Form Health Survey 36 (SF-36), but no significant effect on the disability Index and the EQ-5D (instrument for describing and valuing health, based on a descriptive system that defines health in terms of five dimensions: Mobility, Self-Care, Usual Activities, Pain/Discomfort, and Anxiety/Depression). Duloxetine was generally well tolerated, although dizziness, decreased intellectual performance, and somnolence could be noted.

Duloxetine had a level $\mathrm{C}$ of recommendation (possibly effective) to treat CNP because of two positive studies in the treatment of multilpe sclerosis (MS)-related CNP, and one negative study in the treatment of SCI and poststroke CNP. However, the studies used in this recommendation were very homogeneous $\left(\mathrm{I}^{2}=0 \%\right)$, and effect size was moderate (0.73[0.39-1.06]) (Supplementary Figure S3), making the quantitative synthesis very consistent. Hence, the consensus panel upgraded the level of recommendation to B (probably effective) for the use of duloxetine in the treatment of CNP. In accordance with this recommendation, duloxetine had a lower number needed to treat (NNT) (6.4) than gabapentinoids in a recent guideline for neuropathic pain in general ${ }^{48}$.

\section{Gabapentin}

Gabapentin was used to treat CNP in spinal cord injury in a class II, low-quality, positive study ${ }^{29}$. Paraplegic patients with pain were treated for four weeks with stable doses of up to $3,600 \mathrm{mg} /$ day, after a four weeks period of titration. The treatment was efficient in reducing $>50 \%$ pain intensity, frequency, and almost all neuropathic pain descriptors assessed (hot, sharp, unpleasantness, deep pain, and surface pain), also improving quality of life, assessed by non-standard instruments (Lattinen test). Considering the total number of adverse effects, which included weakness, edema, vertigo, 
sedation, headache, and itching, it was significantly higher in patients treated with gabapentin when compared to the placebo group.

Gabapentin reached a level $\mathrm{C}$ of recommendation (probably effective) in the treatment of CNP. This was based on only one positive class II study, with a high effect size (4.30[3.74-4.86], $\mathrm{P}<0.001)$ (Supplementary Figure S4), independent of its low quality. Other guidelines present gabapentin as a first-line drug in the treatment of neuropathic pain in general ${ }^{48}$. However, similar to pregabalin, gabapentin's NNT for the treatment of NP, in general, is very high (7.2). As this drug may also be a reasonable option for CNP, future studies should improve in quality, sample size, and diversity of CNP syndromes, in order to investigate its specific efficacy.

\section{Amitriptyline (and other tricyclics antidepressants)}

Leijon et al. (1989) compared amitriptyline vs. carbamazepine and placebo interventions in periods of four weeks, in a low-quality, class II, positive study ${ }^{19}$. Using final doses of $75 \mathrm{mg} /$ day for amitriptyline, they found statistical significance between groups for average pain intensity in central poststroke pain. Outcome measures included the assessment of pain intensity and depression. Amitriptyline produced a small decrease in pain intensity, an effect related to the plasma concentration of the drug, with good tolerance to the final dose.

Amitriptyline was attributed a level C (possibly effective) in the treatment of CNP because of one positive study in the treatment of post-stroke CNP. This study was not included in quantitative synthesis, as although they reported mean and standard deviations as statistical measures, their analysis of significance was based on non-parametric tests, making means obsolete measures (Supplementary Figure S5). However, as this drug is widely available in Brazil, at low cost and generally considered a first-line medication in the treatment of neuropathic pain in general ${ }^{48,49}$, the consensus panel opted to maintain it as a first-line medication in the control of CNP. The use of pregabalin, gabapentin, duloxetine and amitriptyline as first-line drugs in the treatment of CNP is in accordance with other guidelines for NP in general ${ }^{48,49,50}$. However, it should be mentioned that CNP is more refractory than peripheral $\mathrm{NP}^{51}$, making the development of new clinical trials investigating their effectiveness in larger samples necessary, with different doses, and together with other pharmacological and non-pharmacological approaches.

\section{Second-line therapy}

\section{Pregabalin}

The use of pregabalin for the treatment of CNP in spinal cord injury was based on three positive $e^{20,21,22}$ and one negative $^{31}$ studies. The first was a low-quality, positive study ${ }^{20}$, which had more than 25 individuals per study arm, but was downgraded to class II due to problems in blinding and attrition bias. They used 150, 300, or $600 \mathrm{mg} /$ day of the drug, twice a day, for 12 weeks. Results showed a dose-dependent effect, with the medium dose of $460 \mathrm{mg} /$ day being more effective than the placebo in controlling pain. Active intervention was associated with decreased The short-form McGill Pain Questionnaire (SF-MPQ) scores, sleep problems, and anxiety. Patients' impression of change was greater in the active group. Adverse events were seen in $75 \%$ of the participants in the placebo group and $96 \%$ in the active group, being severe in $12 \%$ of the placebo and in $19 \%$ of the active group. Somnolence and dizziness were the most frequent adverse events, and euphoria was also reported, though only in the active group. The second report was a high-quality, positive, class II study ${ }^{22}$, which used 150 to $600 \mathrm{mg}$ of the drug, depending on the participants' responses to the intervention during four weeks. The intervention was effective for pain relief, measured through the Pain Disability Index, and the results were slightly positive for quality of life through EQ-5D and in the bodily of the SF-36. Pregabalin, in a flexible-dose regime, produced clinically significant reductions in pain intensity, as well as improvements in health status. The most frequently reported adverse events were central nervous system-related (dizziness, decreased intellectual performance, and somnolence) and nausea. The incidence of these adverse events (mild or moderate in intensity), however, did not differ significantly between treatment groups.

The third report was a high-quality, positive, class I study $^{21}$, which used a maximum of $600 \mathrm{mg} /$ day, for 12 weeks. Results showed a significant decrease in pain intensity, with almost $50 \%$ of the pregabalin group vs. $31.4 \%$ in the control group, achieving $>30 \%$ of pain intensity relief. Positive differences were also seen in sleep quality and depression, but not in anxiety. The fourth study was the largest, with 219 participants allocated to the active or placebo groups. This negative high-quality class I study used doses of 150 to $600 \mathrm{mg}$ /day for 12 weeks to treat CPSP. Results were negative for pain relief, but positive for improving sleep, anxiety, and global impression of change. However, adverse events were more frequent in the active group.

Based on the level of evidence alone, (presence of one class I and two class II positive, and one class I negative studies), the drug received a recommendation level B (probably beneficial). However, this recommendation was not supported by quantitative synthesis, as although the overall effect size was positive (0.89[0.23-1.56], $\mathrm{P}<0.01)$ (Supplementary Figure S6), the heterogeneity of the studies was high $\left(I^{2}=85 \%\right)$. Hence, based on the imprecision of the effect size ${ }^{52}$, the level of recommendation for the use of pregabalin in the treatment of CNP was downgraded to level $\mathrm{C}$ (possibly effective) by the consensus panel. This is in accordance with recent guidelines for the treatment of NP in general ${ }^{53}$, but points toward an urgent need to improve the quality of studies in the area. The NNT of pregabalin in the treatment of peripheral and CNP was recently estimated between 7.7 (6.5-9.4)and more than 9 
including the most recent studies ${ }^{48,53}$. These are high values, and would probably be higher in cases of CNP exclusively.

\section{Weak opioids (in particular tramadol)}

Tramadol, a weak mu-agonist which centrally acts in serotonin and noradrenaline reuptake inhibition, is a second-line therapy for NP according to current guidelines ${ }^{3,54}$. However, according to a recent systematic review, there is not enough data of adequate quality to provide convincing evidence that tramadol is effective in relieving $\mathrm{NP}^{54,55}$. Besides, along with all other opioid drugs, it has barely been studied specifically in CNP patients. A single positive controlled study evaluated tramadol in $\mathrm{CNP}$ due to $\mathrm{SCI}^{55}$; none were performed in CPSP and MS-CNP patients.

\section{Lamotrigine}

The use of lamotrigine in the control of CNP was investigated in three studies. In the first study, Vestergaard et al. used $25,50,100$, or $200 \mathrm{mg}$ lamotrigine to treat poststroke CNP, a high-quality, class II, positive study ${ }^{17}$. Patients were treated for eight weeks, followed by a two-week washout period. The active group showed a small decrease in median pain intensity with the $200 \mathrm{mg}$ dose only. Effects were also seen in the physical pain item of the Global Pain Rating, and in the acetone drop test, highlighting the potential use of this drug in the control of cold allodynia present in CNP. The adverse effects of the drug were similar to those of placebo. This study was not included in quantitative synthesis, as they reported only the median as a central tendency measure.

In the second study, Finnerup et al. (2002), in a high-quality, class II, negative RCT study using lamotrigine (maximum 400mg for 9 weeks) in spinal cord injury CNP, have found no reduction in pain intensity, spasticity, sleep interference, and quality of life in 42 patients ${ }^{14}$. However, they observed that, for patients with incomplete spinal cord injury, there were significant reductions in at or below-level pain, tactile, pressure, and warm threshold, compared with complete spinal cord lesion. Lamotrigine was generally well tolerated, being necessary for only one patient to be withdrawn due to a rash. In the third study, Breuer et al. used increasing doses of lamotrigine, up to $400 \mathrm{mg} /$ day to treat multiple sclerosis-related CNP in a high-quality, class II, negative study ${ }^{23}$. Patients were treated for eight weeks, and the results showed no effects on none of the outcome measures, directed to assess pain intensity and its impact on daily life (mean pain - 0.80 [-1.55 - 3.15, $\mathrm{P}=0.5]$ (Supplementary Figure S7), neuropathic pain characteristics or quality of life. In this study, adverse effects were more frequent in the active group. As only the study of Breuer et al. ${ }^{23}$ could be included in the quantitative synthesis, it was not possible to pool all three studies in the meta-analysis. The consensus panel attributed a level B of recommendation (possibly ineffective) to the use of lamotrigine to treat post-stroke, spinal cord injury, and multiple sclerosis-related CNP. However, analysis of individual included studies shows that it may help in the control of some characteristics of CNP, such as painful spasms, paroxysms, and the presence of the Lhermitte's sign-related pain.

\section{Venlafaxine}

The use of venlafaxine in the treatment of CNP was not investigated in any of the included studies. Analgesic effects are due to central noradrenergic effects, obtained with higher doses of venlafaxine $(150-225 \mathrm{mg} / \text { day })^{12,48}$, being titrated from 37.5mg up and in some cases being used $300 \mathrm{mg} /$ day. Advent or worsening of high blood pressure must be monitored during treatment ${ }^{56}$. Hence, according to the specialists' opinions, it may be considered as a second-line option or an alternative for duloxetine. CNP specific investigations are suggested. Also, venlafaxine is a good option to treat commonly CNP-related anxiety and depressive disorders.

\section{Third-line therapy}

\section{Strong opioids (methadone, morphine, oxycodone, buprenorphine, fentanyl)}

Most studies with opioids in NP evaluated post-herpetic neuralgia and other painful peripheral neuropathies from different etiologies. As already mentioned above, no controlled study has evaluated the use of strong opioids in the treatment of CNP. A recent systematic review on the efficacy, tolerability, and safety of opioids in non-cancer NP ponders that opioids may have a short-term substantial pain relief in highly selected patients in some NP syndromes ${ }^{57}$. Despite the lack of good quality evidence, strong opioids - especially methadone and morphine, affordable and accessible in the Brazilian health system - have been used for CNP in patients refractory to treatment as an add-on therapy to first-line medications in referred pain centers in Brazil. There is an obvious need for quality-controlled studies to clarify the role of strong opioids in the treatment of CNP.

\section{Cannabinoids}

The use of specific cannabinoid combinations (delta9-tetrahydrocannabinol (THC)/Cannabidiol (CBD) for the treatment of CNP was based on three positive and two negative studies. Rog et al. developed a high-quality class I study using $\mathrm{CBD} / \mathrm{THC}$ to treat MS-related $\mathrm{CNP}^{37}$. The drug was administered at doses of eight (21.6mg THC: 20mg CBD) to 48 (129.6mg THC: 120mg CBD) sprays daily, for five weeks. There was a reduction of $41.5 \%$ in the pain numeric rating scale (NRS), and $32.0 \%$ in the neuropathic pain scale (NPS) in the active group, with a reduction of $22.1 \%$ in the NRS, and $17.6 \%$ in the NPS in the sham group. There was also improvement in sleep in the active group, but no influence on anxiety and depression scale or disability. The placebo group improved in neurophysiological testing. Adverse events were identified in $88.2 \%$ of patients in the active group and $68.8 \%$ in the placebo group and were mainly with central characteristics in 
the active group. Berman et al. used a cannabinoid-based approach (CBD/THC) to treat pain in brachial plexus injury in a low-quality, class II, negative study ${ }^{32}$. The treatment consisted of THC $21.6 \mathrm{mg}$, THC $21.6 \mathrm{mg} / \mathrm{CBD} 20 \mathrm{mg}$ or placebo, four to eight times a day, for seven to 24 days. The results were significant, but not clinically relevant in decreasing pain intensity, and improving sleep. Adverse events were small, present only in one participant in each group. Svendsen et al. showed in a high-quality, class II, positive study that dronabinol (cannabinoid), 2.5-5 mg, twice a day, for three weeks was effective in the control of CNP in multiple sclerosis ${ }^{33}$. The intervention decreased more than $50 \%$ of pain intensity in almost half of the participants in the active group (42-50\%, depending on the order of crossover administration), compared to 8 to $25 \%$ in the placebo group. Improvement in radiating pain, pressure pain threshold, and mental health (SF-36) were seen in the active group. High adverse events were observed in the first week, being mainly central and musculoskeletal complaints, and were found in $96 \%$ of the participants in the active group, against $46 \%$ in the control group. Langford et al. published a low-quality, class II, negative study using THC/CBD oro-mucosal spray for 14 weeks in combination in CNP in 339 patients with multiple sclerosis in an RCT and found differences in pain NRS and sleep quality without difference between the respondents in phase I of the study ${ }^{57}$. Patients experienced no severe adverse events involving dizziness, fatigue, somnolence, vertigo, and nausea. Schimrigk et al..$^{28}$ published a low-quality class II study using dronabinol to treat MS CNP, for 16 weeks. Dronabinol was not superior to placebo in decreasing pain intensity, and the presence of adverse effects was higher in the active group.

The consensus panel recommended against the use of cannabinoids as monotherapy for the treatment of CNP, based on two positive and two negative studies. Cannabis-based drugs were considered as a third-line treatment, as an add-on drug or an alternative for opioids in selected refractory patients. This recommendation is in accordance with the quantitative synthesis, as the overall effect size was not significant (0.63 [-0.04 - 1.30], $\mathrm{P}=0.07)$ (Supplementary Figure S8), and with high heterogeneity $\left(\mathrm{I}^{2}=74 \%\right)$. Also, among the four studies included, formulations and doses were quite heterogeneous, and the quality of the studies was low in two of them. This recommendation is in line with a recent review that failed to show beneficial effects in the treatment of neuropathic pain in general ${ }^{58}$. Furthermore, at the present moment, cannabis-based drugs are not fully available in the Brazilian public health system and are actually very high-cost medications, which is likely to change in the years to come.

\section{Combination of first-, second- and third-line drugs}

A minority of CNP patients have full control of pain with a single drug. Monotherapy often leads to a limited analgesic effect and dose-related side effects. In clinical practice, the combination of drugs has been frequently used by specialists in order to obtain a minimum satisfactory control of pain, of comorbidities commonly associated with CNP such as depression, anxiety, and sleep disorders, and to help patients improve functionality and quality of life. The combination of drugs may potentiate analgesic effects due to synergistic properties and possibly allow the use of lower doses and minimize the occurrence of adverse effects. However, studies that evaluated the combination of drugs in chronic pain are scarce, mostly evaluated peripheral neuropathic pain, and none was performed in CNP. A systematic review on combined pharmacotherapy in NP pointed out that good quality studies have demonstrated superior efficacy of different two-drug combinations, but it could not recommend the use of any specific combination of drugs due to the limited trial sizes and duration ${ }^{59}$. Gabapentinoids have been commonly used in association with other drugs for the treatment of NP patients. The absence of drug interactions and hepatic metabolism favors its combination with other drugs such as the serotonin-norepinephrine reuptake inhibitors (SNRI), for instance. However, safety concerns have been brought about the combination of gabapentinoids and opioids. Gomes et al. described an increased risk for opioid-related death due to respiratory depression in patients taking gabapentinoids ${ }^{60}$.

\section{Drugs classically used for neuropathic pain \\ in general or CNP in particular, in Brazil, and potentially able to benefit some patients}

\section{Carbamazepine}

Leijon et al., in a low quality, class II, negative study, compared carbamazepine $v s$. placebo intervention in periods of four weeks, using final doses of $800 \mathrm{mg} /$ day, and found no statistical significance between groups for mean pain intensity in central poststroke pain ${ }^{19}$. Outcome measures included the assessment of pain intensity and depression. Carbamazepine was not effective and produced several adverse effects, generating high dropout rates during the segment study. Carbamazepine has been classically used to treat trigeminal neuralgia. In CNP, despite the paucity of studies, it can also be useful to treat shock-like, paroxysmal $\mathrm{NP}$, especially in SCI (e.g. Lhermitte's sign), even at low doses. In addition, carbamazepine is an affordable and widely available drug in Brazil, even in SUS. Further studies are needed to establish a role for carbamazepine in patients in specific subsets of CNP.

\section{Summary of classification of selected studies}

Based on these results and taking into account the positive or negative effects of the drugs, specialists' opinions, balancing their adverse effects, cost, and availability in SUS, Table 1, Figure 2 and Box 1 summarize the results of the consensus panel according to the use of drugs to treat CNP in Brazil. 


\section{Central Neuropathic \\ First-line pharmacological therapy}

Duloxetine (60-120 mg/day) for MS-pain and CNP-related psychiatric comorbidities, level B (probably effective)

Gabapentin (900-3,600mg/day) to treat CNP and NP symptoms (evoked-pain or allodynia), level C (possibly effective)

Tricyclic antidepressants $(25-150 \mathrm{mg} /$ day) to treat CNP, level C (possibly effective)

Second-line pharmacological therapy

Pregabalin (150-600 mg/day) for SCI and evoked-CNP or allodynia, level C (possibly effective)

Weak opioids (in particular tramadol) in association with first-line drugs (not monotherapy), absence of experimental evidence

Lamotrigine (50-200 mg/day) for CPSP and at or below-level pain in SCI, level B (probably ineffective)

Venlafaxine $(150-225 \mathrm{mg} /$ day $)$ to treat CNP and CNP-related anxiety and depressive disorders, absence of experimental evidence

\section{Third-line pharmacological therapy}

Strong opioids (methadone and oxycodone) + first-line drugs in refractory CNP (not monotherapy), absence of experimental evidence

Cannabidiol (CBD) / Delta-9-Tetrahydrocannabinol (THC) (refer to text for dosing) and Dronabinol (2.5-5.0mg $2 \mathrm{x}$ day) for CNP refractory to first- and second-line therapies above and in MS-related pain (in selected patients may be tried as monotherapy), conflicting results, not to be used as monotherapy

Drugs classically used for NP in general or CNP in particular in Brazil and likely to benefit some patients: Carbamazepine to treat shock-like, paroxysmal NP, especially in spinal cord injury central neuropathic pain (e.g. Lhermitte's sign, painful spasms).

Combination of first-, second-, and third-line drugs should be considered.

Figure 2. Central Neuropathic Pain guideline.

\section{Special issues in prescribing drugs for CNP}

\section{Is pain in central nervous system (CNS)}

diseases always central neuropathic?

CNP happens after lesion or dysfunction of the CNS and is associated with signs of central hyperexcitability, loss of sensation, spontaneous and/or abnormally evoked pain, and other characteristics of maladaptive plasticity - plasticity leading to decreased function in the $\mathrm{CNS}^{61}$. However, as signs and symptoms are very remarkable, little attention is put on other possible sources of pain, including nociceptive and nociplastic pain. Other sources of pain in patients with CNP include spasticity and spasms related pain $^{62,63}$, musculoskeletal pain secondary to joint, muscle or myofascial dysfunction ${ }^{63,64}$, fatigue ${ }^{65}$, migraine and tension-type headache ${ }^{66}$, treatment pain ${ }^{67,68}$, peripheral neuropathy ${ }^{69}$, and central sensitization or nociplastic pain $^{70}$. Importantly, a recent study found that seven out of eight patients with post-stroke CNP were relieved by a peripheral nerve block, suggesting that peripheral components may have an important role in $\mathrm{CNP}^{71}$. Hence, a thorough evaluation of pain sources should contribute to the understanding of the true role of central and peripheral mechanisms associated with CNP. 
UPDATING PROCEDURE

The consensus will meet every five years to update the recommendations. At that time the initial panel of experts will be invited to participate, as well as other representatives of Brazilian associations involved in the management of CNP. The procedure to update the recommendations will follow the guidelines in force to report such studies.

\section{References}

1. Treede RD, Rief W, Barke A, Aziz Q, Bennett MI, Benoliel R, et al. Chronic pain as a symptom or a disease: the IASP Classification of Chronic Pain for the International Classification of Diseases (ICD-11). Pain. 2019 Jan;160(1):19-27. https://doi.org/10.1097/j. pain. 0000000000001384

2. Sá KN, Moreira L, Baptista AF, Yeng LT, Teixeira MJ, Galhardoni R, et al. Prevalence of chronic pain in developing countries: systematic review and meta-analysis. Pain Rep. 2019 Dec;4(6):e779. https://doi. org/10.1097/pr9.0000000000000779

3. Finnerup NB, Haroutounian S, Kamerman P, Baron R, Bennett DL, Bouhassira D, et al. Neuropathic pain: an updated grading system for research and clinical practice. Pain. 2016 Aug;157(8):1599-606. https://doi.org/10.1097/j.pain.0000000000000492

4. van Hecke O, Austin SK, Khan RA, Smith BH, Torrance N. Neuropathic pain in the general population: a systematic review of epidemiological studies. Pain. 2014 Sep;155(4):654-62. https://doi. org/10.1016/j.pain.2013.11.013

5. de Moraes Vieira EB, Garcia JB, da Silva AA, Mualem Araujo RL, Jansen RC. Prevalence, characteristics, and factors associated with chronic pain with and without neuropathic characteristics in Sao Luis, Brazil. J Pain Symptom Manage. 2012 Aug;44(2):239-51. https:// doi.org/10.1016/j.jpainsymman.2011.08.014

6. Andersen G, Vestergaard K, Ingeman-Nielsen M, Jensen TS. Incidence of central post-stroke pain. Pain. 1995 May;61(2):187-93. https://doi.org/10.1016/0304-3959(94)00144-4

7. Modirian E, Pirouzi P, Soroush M, Karbalaei-Esmaeili S, Shojaei $\mathrm{H}$, Zamani H. Chronic pain after spinal cord injury: results of a long-term study. Pain Med. 2010 Jul;11(7):1037-43. https://doi. org/10.1111/j.1526-4637.2010.00865.x

8. Moisset X, Ouchchane L, Guy N, Bayle DJ, Dallel R, Clavelou P. Migraine headaches and pain with neuropathic characteristics: comorbid conditions in patients with multiple sclerosis. Pain. 2013 Dec;154(12):2691-9. https://doi.org/10.1016/j.pain.2013.07.050

9. Klit H, Finnerup NB, Jensen TS. Central post-stroke pain: clinical characteristics, pathophysiology, and management. Lancet Neurol. 2009 Sep;8(9):857-68. https://doi.org/10.1016/s14744422(09)70176-0

10. Vranken JH. Elucidation of pathophysiology and treatment of neuropathic pain. Cent Nerv Syst Agents Med Chem. 2012 Dec;12(4):304-14. https://doi.org/10.2174/187152412803760645

11. Dworkin RH, O'Connor AB, Backonja M, Farrar JT, Finnerup NB, Jensen TS, et al. Pharmacologic management of neuropathic pain: evidence-based recommendations. Pain. 2007 Dec;132(3):237-51. https://doi.org/10.1016/j.pain.2007.08.033

12. Moisset X, Bouhassira D, Avez Couturier J, Alchaar H, Conradi S, Delmotte $\mathrm{MH}$, et al. Pharmacological and non-pharmacological treatments for neuropathic pain: Systematic review and French recommendations. Rev Neurol (Paris). 2020 May;176(5):325-52. https://doi.org/10.1016/j.neurol.2020.01.361

13. Brouwers MC, Kerkvliet K, Spithoff K, Consortium ANS. The AGREE Reporting Checklist: a tool to improve reporting of clinical practice guidelines. BMJ. 2016 Mar;352:i1 152. https://doi.org/10.1136/bmj.i1152

14. Finnerup NB, Sindrup SH, Bach FW, Johannesen IL, Jensen TS. Lamotrigine in spinal cord injury pain: a randomized controlled trial. Pain. 2002 Apr;96(3):375-83. https://doi.org/10.1016/s03043959(01)00484-5
15. Jungehulsing GJ, Israel H, Safar N, Taskin B, Nolte CH, Brunecker P, et al. Levetiracetam in patients with central neuropathic post-stroke pain--a randomized, double-blind, placebo-controlled trial. Eur J Neurol. 2013 Feb;20(2):331-7. https://doi.org/10.1111/j.14681331.2012.03857.x

16. Drewes AM, Andreasen A, Poulsen LH. Valproate for treatment of chronic central pain after spinal cord injury. A double-blind cross-over study. Paraplegia. 1994 Aug;32(8):565-9. https://doi. org/10.1038/sc.1994.89

17. Vestergaard K, Andersen G, Gottrup H, Kristensen BT, Jensen TS. Lamotrigine for central poststroke pain: a randomized controlled trial. Neurology. 2001 Jan;56(2):184-90. https://doi.org/10.1212/ wnl.56.2.184

18. Higgins JPT, Li T, Deeks JJ. Choosing effect measures and computing estimates of effects [Internet]. In: Higgins JPT, Thomas J, Chandler J, Cumpston M, Li T, Page MJ, et al., editors. Cochrane Handbook for Systematic Reviews of Interventions. 2nd ed. Chichester (UK): WileyBlackwell; 2019. p. 143-76.

19. Leijon G, Boivie J. Central post-stroke pain--a controlled trial of amitriptyline and carbamazepine. Pain. 1989 Jan;36(1):27-36. https://doi.org/10.1016/0304-3959(89)90108-5

20. Siddall PJ, Cousins MJ, Otte A, Griesing T, Chambers R, Murphy TK. Pregabalin in central neuropathic pain associated with spinal cord injury: a placebo-controlled trial. Neurology. 2006 Nov;67(10):1792800. https://doi.org/10.1212/01.wnl.0000244422.45278.ff

21. Cardenas DD, Nieshoff EC, Suda K, Goto S, Sanin L, Kaneko T, et al. A randomized trial of pregabalin in patients with neuropathic pain due to spinal cord injury. Neurology. 2013 Feb;80(6):533-9. https://doi. org/10.1212/wnl.0b013e318281546b

22. Vranken JH, Dijkgraaf MG, Kruis MR, van der Vegt MH, Hollmann MW, Heesen M. Pregabalin in patients with central neuropathic pain: a randomized, double-blind, placebo-controlled trial of a flexible-dose regimen. Pain. 2008 May;136(1-2):150-7. https://doi.org/10.1016/j. pain.2007.06.033

23. Breuer B, Pappagallo M, Knotkova H, Guleyupoglu N, Wallenstein S, Portenoy RK. A randomized, double-blind, placebo-controlled, twoperiod, crossover, pilot trial of lamotrigine in patients with central pain due to multiple sclerosis. Clin Ther. 2007 Sep;29(9):2022-30. https://doi.org/10.1016/j.clinthera.2007.09.023

24. Falah M, Madsen C, Holbech JV, Sindrup SH. A randomized, placebocontrolled trial of levetiracetam in central pain in multiple sclerosis. Eur J Pain. 2012 Jul;16(6):860-9. https://doi.org/10.1002/j.15322149.2011.00073.x

25. Langford RM, Mares J, Novotna A, Vachova M, Novakova I, Notcutt W, et al. A double-blind, randomized, placebo-controlled, parallelgroup study of THC/CBD oromucosal spray in combination with the existing treatment regimen, in the relief of central neuropathic pain in patients with multiple sclerosis. J Neurol. 2013 Apr;260(4):984-97. https://doi.org/10.1007/s00415-012-6739-4

26. Brown TR, Slee A. A randomized placebo-controlled trial of duloxetine for central pain in multiple sclerosis. Int J MS Care. 2015 Mar-Apr;17(2):83-9. https://doi.org/10.7224/1537-2073.2014-001

27. Vollmer TL, Robinson MJ, Risser RC, Malcolm SK. A randomized, double-blind, placebo-controlled trial of duloxetine for the treatment of pain in patients with multiple sclerosis. Pain Pract. 2014 Nov;14(8):732-44. https://doi.org/10.1111/papr.12127 
28. Schimrigk S, Marziniak M, Neubauer C, Kugler EM, Werner G, Abramov-Sommariva D. Dronabinol Is a Safe Long-Term Treatment Option for Neuropathic Pain Patients. Eur Neurol. 2017 Oct;78(56):320-9. https://doi.org/10.1159/000481089

29. Levendoglu F, Ogun CO, Ozerbil O, Ogun TC, Ugurlu H. Gabapentin is a first line drug for the treatment of neuropathic pain in spinal cord injury. Spine (Phila Pa 1976). 2004 Apr;29(7):743-51. https://doi. org/10.1097/01.brs.0000112068.16108.3a

30. Vranken JH, Hollmann MW, van der Vegt MH, Kruis MR, Heesen M, Vos K, et al. Duloxetine in patients with central neuropathic pain caused by spinal cord injury or stroke: a randomized, double-blind, placebo-controlled trial. Pain. 2011 Feb;152(2):267-73. https://doi. org/10.1016/j.pain.2010.09.005

31. Kim JS, Bashford G, Murphy TK, Martin A, Dror V, Cheung R. Safety and efficacy of pregabalin in patients with central post-stroke pain. Pain. 2011 May;152(5):1018-23. https://doi.org/10.1016/j. pain. 2010.12.023

32. Berman JS, Symonds C, Birch R. Efficacy of two cannabis based medicinal extracts for relief of central neuropathic pain from brachial plexus avulsion: results of a randomised controlled trial. Pain. 2004 Dec;112(3):299-306. https://doi.org/10.1016/j. pain.2004.09.013

33. Svendsen KB, Jensen TS, Bach FW. Does the cannabinoid dronabinol reduce central pain in multiple sclerosis? Randomised double blind placebo controlled crossover trial. BMJ. 2004 Jul;329(7460):253. https://doi.org/10.1136/bmj.38149.566979.ae

34. Ahn SH, Park HW, Lee BS, Moon HW, Jang SH, Sakong J, et al. Gabapentin effect on neuropathic pain compared among patients with spinal cord injury and different durations of symptoms. Spine (Phila Pa 1976). 2003 Feb;28(4):341-6; discussion 6-7. https://doi. org/10.1097/01.brs.0000048464.57011.00

35. Attal N, Brasseur L, Parker F, Chauvin M, Bouhassira D. Effects of gabapentin on the different components of peripheral and central neuropathic pain syndromes: a pilot study. Eur Neurol. 1998 Nov;40(4):191-200. https://doi.org/10.1159/000007979

36. Kim NY, Lee SC, Kim YW. Effect of Duloxetine for the Treatment of Chronic Central Poststroke Pain. Clin Neuropharmacol. 2019 May/ Jun;42(3):73-6. https://doi.org/10.1097/wnf.0000000000000330

37. Rog DJ, Nurmikko TJ, Young CA. Oromucosal delta9tetrahydrocannabinol/cannabidiol for neuropathic pain associated with multiple sclerosis: an uncontrolled, open-label, 2-year extension trial. Clin Ther. 2007 Sep;29(9):2068-79. https://doi. org/10.1016/j.clinthera.2007.09.013

38. Hesami O, Gharagozli K, Beladimoghadam N, Assarzadegan F, Mansouri B, Sistanizad M. The Efficacy of Gabapentin in Patients with Central Post-stroke Pain. Iran J Pharm Res. 2015 Winter;14(Suppl):95-101. http://www.ncbi.nlm.nih.gov/pmc/articles/pmc4499431/

39. Kalita J, Chandra S, Misra UK. Pregabalin and lamotrigine in central poststroke pain: A pilot study. Neurol India. 2017 MayJun;65(3):506-11. https://doi.org/10.4103/neuroindia.ni_45_16

40. Barrera-Chacon JM, Mendez-Suarez JL, Jauregui-Abrisqueta ML, Palazon R, Barbara-Bataller E, Garcia-Obrero I. Oxycodone improves pain control and quality of life in anticonvulsant-pretreated spinal cord-injured patients with neuropathic pain. Spinal Cord. 2011 Jan;49(1):36-42. https://doi.org/10.1038/sc.2010.101

41. Richards JS, Bombardier CH, Wilson CS, Chiodo AE, Brooks L, Tate $D G$, et al. Efficacy of venlafaxine XR for the treatment of pain in patients with spinal cord injury and major depression: a randomized, controlled trial. Arch Phys Med Rehabil. 2015 Apr;96(4):680-9. https://doi.org/10.1016/j.apmr.2014.11.024

42. Dellapina E, Gerdelat-Mas A, Ory-Magne F, Pourcel L, Galitzky M, Calvas F, et al. Apomorphine effect on pain threshold in Parkinson's disease: a clinical and positron emission tomography study. Mov Disord. 2011 Jan;26(1):153-7. https://doi.org/10.1002/mds.23406

43. Chiou-Tan FY, Tuel SM, Johnson JC, Priebe MM, Hirsh DD, Strayer JR. Effect of mexiletine on spinal cord injury dysesthetic pain.
Am J Phys Med Rehabil. 1996 Mar-Apr;75(2):84-7. https://doi. org/10.1097/00002060-199603000-00002

44. Finnerup NB, Grydehoj J, Bing J, Johannesen IL, Biering-Sorensen F, Sindrup SH, et al. Levetiracetam in spinal cord injury pain: a randomized controlled trial. Spinal Cord. 2009 Dec;47(12):861-7. https://doi.org/10.1038/sc.2009.55

45. Rintala DH, Holmes SA, Courtade D, Fiess RN, Tastard LV, Loubser $P G$. Comparison of the effectiveness of amitriptyline and gabapentin on chronic neuropathic pain in persons with spinal cord injury. Arch Phys Med Rehabil. 2007 Dec;88(12):1547-60. https://doi. org/10.1016/j.apmr.2007.07.038

46. Rossi S, Mataluni G, Codeca C, Fiore S, Buttari F, Musella A, et al. Effects of levetiracetam on chronic pain in multiple sclerosis: results of a pilot, randomized, placebo-controlled study. Eur J Neurol. 2009 Mar;16(3):360-6. https://doi.org/10.1111/j.1468-1331.2008.02496.x

47. Amr YM. Multi-day low dose ketamine infusion as adjuvant to oral gabapentin in spinal cord injury related chronic pain: a prospective, randomized, double blind trial. Pain Physician. 2010 MayJun;13(3):245-9. PMID: 20495588.

48. Finnerup NB, Attal N, Haroutounian S, McNicol E, Baron R, Dworkin $\mathrm{RH}$, et al. Pharmacotherapy for neuropathic pain in adults: a systematic review and meta-analysis. Lancet Neurol. 2015 Feb;14(2):162-73. https://doi.org/10.1016/s1474-4422(14)70251-0

49. Cruccu G, Truini A. A review of Neuropathic Pain: From Guidelines to Clinical Practice. Pain Ther. 2017 Dec;6(Suppl 1):35-42. https://doi. org/10.1007/s40122-017-0087-0

50. Dworkin RH, O'Connor AB, Kent J, Mackey SC, Raja SN, Stacey BR, et al. Interventional management of neuropathic pain: NeuPSIG recommendations. Pain. 2013 Nov;154(11):2249-61. https://doi. org/10.1016/j.pain.2013.06.004

51. Garcia JBS, Barbosa Neto JO, Amâncio EJ, de Andrade ETF. Central neuropathic pain. Revista Dor. 2016;17 (Suppl 1):67-71. https://doi. org/10.5935/1806-0013.20160052

52. Langendam M, Hooft L, Scholten R. GRADE: reasons for downgrading the quality of evidence in recent Cochrane Reviews. Cochrane Colloquium Abstracts [Internet]. 2010 Oct. Available from: https://abstracts.cochrane.org/2010-keystone/grade-reasonsdowngrading-quality-evidence-recent-cochrane-reviews

53. Finnerup NB, Haroutounian S, Baron R, Dworkin RH, Gilron I, Haanpaa M, et al. Neuropathic pain clinical trials: factors associated with decreases in estimated drug efficacy. Pain. 2018 Nov;159(11):2339-46. https://doi.org/10.1097/j. pain. 0000000000001340

54. Guy SD, Mehta S, Casalino A, Cote I, Kras-Dupuis A, Moulin DE, et al. The CanPain SCI Clinical Practice Guidelines for Rehabilitation Management of Neuropathic Pain after Spinal Cord: Recommendations for treatment. Spinal Cord. 2016 Aug;54 Suppl 1:S14-23. https://doi.org/10.1038/sc.2016.90

55. Duehmke RM, Derry S, Wiffen PJ, Bell RF, Aldington D, Moore RA. Tramadol for neuropathic pain in adults. Cochrane Database Syst Rev. 2017 Jun;6(6):CD003726. https://doi.org/10.1002/14651858. cd003726.pub4

56. Gallagher HC, Gallagher RM, Butler M, Buggy DJ, Henman MC. Venlafaxine for neuropathic pain in adults. Cochrane Database Syst Rev. 2015 Aug;2015(8):CD011091. https://doi.org/10.1002/14651858. cd011091.pub2

57. Sommer C, Klose P, Welsch P, Petzke F, Hauser W. Opioids for chronic non-cancer neuropathic pain. An updated systematic review and meta-analysis of efficacy, tolerability and safety in randomized placebo-controlled studies of at least 4 weeks duration. Eur J Pain. 2020 Jan;24(1):3-18. https://doi.org/10.1002/ejp.1494

58. Mücke M, Phillips T, Radbruch L, Petzke F, Hauser W. Cannabisbased medicines for chronic neuropathic pain in adults. Cochrane Database Syst Rev. 2018 Mar;3(3):CD012182. https://doi. org/10.1002/14651858.cd012182.pub2 
59. Chaparro LE, Wiffen PJ, Moore RA, Gilron I. Combination pharmacotherapy for the treatment of neuropathic pain in adults. Cochrane Database Syst Rev. 2012 Jul;2012(7):CD008943. https:// doi.org/10.1002/14651858.cd008943.pub2

60. Gomes T, Greaves S, van den Brink W, Antoniou T, Mamdani MM, Paterson JM, et al. Pregabalin and the Risk for Opioid-Related Death: A Nested Case-Control Study. Ann Intern Med. 2018 Nov;169(10):732-4. https://doi.org/10.7326/m18-1136

61. Harrison RA, Field TS. Post stroke pain: identification, assessment, and therapy. Cerebrovasc Dis. 2015;39(3-4):190-201. https://doi. org/10.1159/000375397

62. Finnerup NB. Neuropathic pain and spasticity: intricate consequences of spinal cord injury. Spinal Cord. 2017 Dec;55(12):1046-50. https://doi.org/10.1038/sc.2017.70

63. Sommer C, Leinders M, Uceyler N. Inflammation in the pathophysiology of neuropathic pain. Pain. 2018 Mar;159(3):595602. https://doi.org/10.1097/j.pain.0000000000001122

64. de Oliveira RA, de Andrade DC, Machado AG, Teixeira MJ. Central poststroke pain: somatosensory abnormalities and the presence of associated myofascial pain syndrome. BMC Neurol. 2012 Sep;12:89. https://doi.org/10.1186/1471-2377-12-89

65. Choi-Kwon S, Choi SH, Suh M, Choi S, Cho KH, Nah HW, et al. Musculoskeletal and central pain at 1 year post-stroke: associated factors and impact on quality of life. Acta Neurol Scand. 2017 Apr;135(4):419-25. https://doi.org/10.1111/ane.12617
66. Øie LR, Kurth T, Gulati S, Dodick DW. Migraine and risk of stroke.J Neurol Neurosurg Psychiatry. 2020 Jun;91(6):593-604. https://doi. org/10.1136/jnnp-2018-318254

67. Eldahan KC, Williams HC, Cox DH, Gollihue JL, Patel SP, Rabchevsky AG. Paradoxical effects of continuous high dose gabapentin treatment on autonomic dysreflexia after complete spinal cord injury. Exp Neurol. 2020 Jan;323:113083. https://doi.org/10.1016/j. expneurol.2019.113083

68. Zecca C, Antozzi CG, Torri Clerici V, Ferrazzini M, Mantegazza RE, Rossi S, et al. Severe multiple sclerosis reactivation during prolonged lymphopenia after dimethyl fumarate discontinuation. Acta Neurol Scand. 2018 Jun;137(6):623-5. https://doi.org/10.1111/ane.12882

69. Khan A, Kamran S, Ponirakis G, Akhtar N, Khan R, George P, et al. Peripheral neuropathy in patients with multiple sclerosis. PLoS One. 2018 Mar;13(3):e0193270. https://doi.org/10.1371/journal.pone.0193270

70. Doolen S, Iannitti T, Donahue RR, Shaw BC, Grachen CM, Taylor BK. Fingolimod reduces neuropathic pain behaviors in a mouse model of multiple sclerosis by a sphingosine-1 phosphate receptor 1-dependent inhibition of central sensitization in the dorsal horn. Pain. 2018 Feb;159(2):224-38. https://doi.org/10.1097/j. pain.0000000000001106

71. Haroutounian S, Ford AL, Frey K, Nikolajsen L, Finnerup NB, Neiner $A$, et al. How central is central poststroke pain? The role of afferent input in poststroke neuropathic pain: a prospective, open-label pilot study. Pain. 2018 Jul;159(7):1317-24. https://doi.org/10.1097/j. pain.0000000000001213 